\title{
Navigating stigma through everyday city-making: Gendered trajectories, politics and outcomes in the periphery of Lima
}

Urban Studies

$1-19$

(c) Urban Studies Journal Limited 2021 (c) (i)

Article reuse guidelines: sagepub.com/journals-permissions DOI: $10.1177 / 00420980211044409$ journals.sagepub.com/home/usj @SAGE

\section{Adriana Allen}

University College London, UK

\begin{abstract}
Over the last two decades, a growing body of scholars from the fields of psychology, sociology, law and public health have devoted their attention to examining how and why stigma operates as a form of discrimination, paying particular attention to ethno-racially stigmatised groups. However, less attention has focused on how ordinary women and men engaged in peripheral urbanisation processes are stigmatised through multiple material, social and political mechanisms and with a myriad of outcomes. Building on this literature, and drawing on the trajectories of a man and a woman living in the periphery of metropolitan Lima, I explore how stigmatisation shapes the daily lives of poor and impoverished citizens as they try to find a place in the city, and how and why their everyday practices contribute, or not, to the transformation of stigma traps. I argue that the everyday city-making practices of the 'unsheltered' are inextricably linked to the politics of bare citizenship. As those stigmatised become individualised, isolated and undermined, they also are deprived of being part of a collective experience, and are deeply challenged to reclaim their agency as entitled citizens. The wider the range of stigmatisation mechanisms at work, the more difficult it is for those subjected to stigma to counteract them, as they become disadvantaged in a broad range of domains: from social relations, to tenure security, access to services and infrastructure, livelihood opportunities, and psychological and physical wellbeing. I further contend that a deep examination of the material world - the dwelling, the neighbourhood and the city - and of the practices and imaginaries that produce this material world, opens a window into the micro-politics of how stigma is negotiated, apportioned and resisted in the everyday lives of those who are politically and materially unsheltered.
\end{abstract}

\section{Keywords}

autoconstruction, everyday urbanism, Lima, peripheral urbanisation, stigma-making, counter-making 


\section{摘要}

在过去的二十年里, 越来越多来自心理学、社会学、法律和公共卫生领域的学者将注意力 集中在研究污名化如何、以及为何作为一种歧视形态存在, 特别关注遭受种族歧视的群体。 然而, 较少学者关注参与外围城市化进程的普通女性和男性如何通过多种物质、社会和政 治机制遭受污名化, 并产生各种各样的结果。借鉴这些文献, 并基于生活在利马大都市外 围的一名男性和一名女性的生活轨迹, 我探索了污名化如何影响贫困公民（他们试图在城 市中找到一席之地）的日常生活, 以及他们的日常做法如何、以及为什么有利于或不利于 污名化陷阱的转变。我认为, “无遮蔽者” 的日常城市生活实践与赤裸公民身份政治密不 可分。随着那些被污名化的人变得个体化、孤立和被削弱, 他们也被剥夺了集体体验, 并 面临着重新获得他们作为有资格公民的能力的严峻挑战。污名化机制起作用的范围越广, 那些遭受污名化的人就越难消除这些机制, 因为他们在广泛的领域处于不利地位: 包括社 会关系和住房保障、享受服务和基础设施的机会、生计机会, 以及心理和身体健康等。我 进一步认为, 对物质世界 (住宅、邻里和城市) 以及产生这个物质世界的实践和想象的深 入考察, 为了解相关的微观政治打开了一扇窗, 在这种微观政治中, 污名化在那些政治上 和物质上无遮蔽者的日常生活中被协商、分配和抵制。

\section{关键词}

自动建设、城市日常、利马、外围城市化、污名制造、反制造

Received January 2020; accepted July 202I

It's funny how life goes ... I come from the provinces and grew up hearing about the promises of Lima, a city where one could aspire to a better life ... I wasn't short of aspirations when I first arrived, but then, little by little, I started to feel undeserving of a better future. Was it because I was dark-skinned and only spoke the language of our ancestors? Was it because I was a single mum with little more than my own hands and a strong will to make a living and build a place I could call home? Yes, it's sort of funny; as time went by, my efforts grew bigger and my dreams smaller. (Estela, Lima, 2015)

This quote comes from Estela, a woman who migrated to Lima in 2010 from the Peruvian countryside in search of a better life for herself and her son. Her story is not exceptional, but speaks to the trajectory of many others who face stigmatisation as they try to call a place 'home'. Throughout the pueblos jóvenes of Lima, cantegrils of Montevideo or favelas of Sao Paulo, everyday city-makers find themselves struggling to secure land, housing, water and sanitation, and, more widely, to participate in the construction of more just urban societies. These conditions are outcomes of widespread inequality, and the expression of quiet institutional and societal processes of stigmatisation.

While stigmatisation as a form of discrimination has been examined from many disciplinary perspectives over the last two decades, little attention has focused on how ordinary women and men navigate stigma as they plan, build and run cities. This requires examining the material and social practices that co-constitute and can potentially counteract stigmatisation. In this article, I explore how stigmatisation shapes the daily lives of poor and impoverished citizens as they try to find a place in the city, and also how and why their everyday practices contribute, or not, to the transformation of stigma traps. 
Building on the study of 'everyday urbanism' (Chase et al., 1999), I argue that stigma traps are reinforced or challenged through a myriad of everyday practices, where the personal, interpersonal, social and political are embedded within each other in the material processes through which cities are socially produced. The everyday city-making practices of the 'unsheltered' are inextricably linked to the politics of bare citizenship. As those stigmatised become individualised, isolated and undermined, they also are deprived of being part of a collective experience, and are deeply challenged when reclaiming their agency as entitled citizens. I contend that a deep examination of the material world - the dwelling, the neighbourhood and the city and of the practices and imaginaries that produce this material world, opens a window into the micro-politics of how stigma is negotiated, apportioned and resisted in the everyday lives of those who are politically and materially unsheltered (Hicks and Lewis, 2020).

Acknowledging that stigmatisation mechanisms, and the practices adopted to counteract them, are multidimensional, I explore the life journeys and everyday strategies of a man and a woman living in the periphery of metropolitan Lima. The narratives presented have been captured through numerous conversations conducted in the city between April 2013 and July 2016.

The following section outlines the genealogy of arguments that have informed the study of stigma and makes a case for foregrounding the materiality and spatiality of stigmatisation processes, to understand how stigma is both experienced and counteracted. This is followed by an examination of the myriad of everyday practices that converge in the peripheral urbanisation of Lima, while setting different trajectories where stigma traps are reinforced or challenged. The third section explores the trajectories of Francisco and Estela, whose stories illustrate the ways that many everyday city-makers try simultaneously to overcome housing insecurity, infrastructural uncertainty and stigmatisation. The final section examines the value of addressing questions of where and when, in order to understand why and under what conditions people like Estela and Francisco can navigate away from stigma traps as they carve their right to the city as a co-created space.

\section{From stigma-making to de-stigmatisation strategies}

In the early 1960s, Erving Goffman's book Stigma: Notes on the Management of Spoiled Identity (Goffman, 1961) imprinted a strong direction in the understanding of stigma, by enquiring into the individual cognitive processing of stigma-relevant information. However, the emphasis on the psychological status of the stigmatised clouded the role of shared social cognition, diluting stigma to 'something in the person rather than a designation or tag that others affix to the person' (Solanke, 2019: 69). This dilution favours an apolitical perspective that treats stigma as a condition carried and transmitted by individuals, thus disregarding the wider dynamics of stigma-making and counter-stigmatisation as social processes (Solanke, 2019).

Critiques of the prevalence of behavioural perspectives portraying those stigmatised as 'helpless victims' (Fine and Asch, 1988) prompted a shift to interrogating how stigmatising processes work and why; acknowledging that the power struggles underpinning the consolidation and overcoming of stigma are fundamentally relational (Reissman, 2000; Tyler and Slater, 2018). Building upon this argument, Link and Phelan (2001) argue that structural stigmatisation operates through five components: labelling, stereotyping, separation, status loss and discrimination. While labelling refers to the attribution and designation 
of difference, stereotyping unveils the undesirable characteristics embedded in those labels as socially constructed beliefs. This leads to the separation between 'us' and 'them', and the consequent status loss and discrimination of those stigmatised. Their perspective is powerful in highlighting that stigma is not a 'thing' but a 'process', which in turns questions why and how stigmatisation operates through social practices and relations.

Surprisingly, when looking at how stigmatisation and de-stigmatisation work for those claiming the city through autoconstruction processes, scholarly attention has typically focused either on macrosociological studies of legal rights endorsed and enforced by the state, or micropsychological examinations of the resistance to, or internalisation of, stigma by its recipients. Instead, I contend that we must capture the everyday practices through which poor and impoverished women and men navigate stigmatisation and counterstigmatisation in the process of building the city and, in doing so, of building their rights and political agency as citizens. As Holston (2009: 246) argues, through contemporary peripheral urbanisation, "new kinds of urban citizens arise to expand democratic citizenships and new forms of urban violence and inequality erode them'.

A first building block for analysis involves observing the range of stigmatising mechanisms deployed in a particular context and situation, which are often subtle, flexible and extensive. Furthermore, as certain stigmatising strategies become ineffective or socially disapproved of, they are often replaced by others. Thus, the wider the range of mechanisms at work, the more difficult it is for those subjected to stigma to counteract them, as they become disadvantaged in a broad range of domains, from social relations to tenure security, access to services and infrastructure and psychological and physical wellbeing.
A second analytical block is that of outcomes. The bulk of studies on stigma focus on single outcomes of stigmatisation, such as eroded self-esteem. But as Link and Phelan (2001) argue, stigmatisation involves status loss, which implies a lower placement in society for those labelled and multiple consequences, many of which might not be obviously linked with the stereotyped beliefs that initially motivated discrimination. For instance, the 'Not in My Back Yard' phenomenon in North Carolina led to the localisation of treatment facilities for people with mental illness into relatively poor and violent areas, thus routinising their victimisation and reinforcing their vulnerability (Dear and Laws, 1986). Furthermore, efforts by those stigmatised to challenge stigma labels might inadvertently lead to further negative outcomes. One example is what Sherman James described as the 'John Henryism' hypothesis - the tendency for some African Americans to work extremely hard to disprove the stereotype of laziness and inability, which in turn leads to lifethreatening hypertension, a stress-related condition that affects Afro-Americans disproportionately (James et al., 1987).

The third analytical building block adopted is that of trajectories, which capture the conditions that explain why some people in stigmatised groups might not suffer the same consequences or outcomes as others. Navigating long-term and relational trajectories enables reading the political agency of those caught in stigmatising processes, not just as something defined by their social identity, self-esteem and capacity to act, but through a wider interplay of social and spatial dialectics (Allen and Hofmann, 2017).

In the following sections, I look into the mechanisms, outcomes and trajectories of everyday city-makers facing stigmatisation and housing, land and infrastructural insecurity, as they carve a space for themselves in the city. 


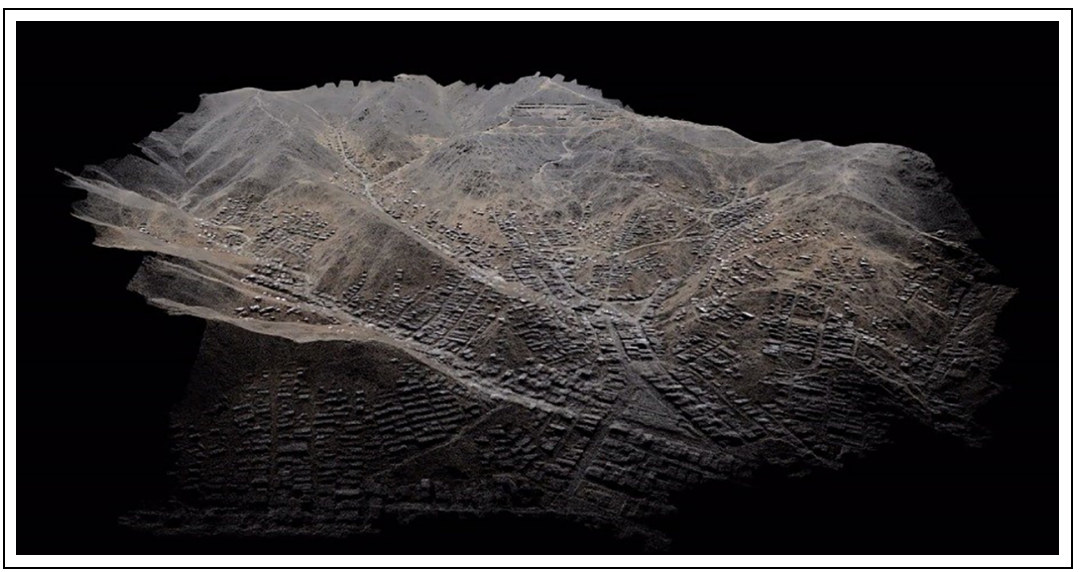

Figure I. Drone-generated image of Jose Carlos Mariátegui, one of the ever-expanding boundaries of metropolitan Lima.

Source: Remap Lima (drone image), DPU UCL (http://remaplima.blogspot.com/).

\section{Everyday city-making in the periphery of Lima}

The two narratives explored tell the stories of a man and a woman living on the upper slopes of the periphery of Metropolitan Lima, in an area known as Jose Carlos Mariátegui (JCM), situated in San Juan de Lurigancho (SJL), Lima's most populated district and one with a high concentration of people living in poverty (Figure 1). JCM consists of numerous barriadas or pueblos jóvenes, encompassing what Caldeira (2017) defines as 'peripheral urbanisation': the processes of auto-construction by which ordinary citizens perform everyday city-making and build cities across the global south.

Caldeira highlights three important features of these processes, which are also important to understand how stigmatisation and de-stigmatisation work through the production of space. First, they are long term, incremental and perennially in the making; second, they interact transversely with the dominant logics of state regulation, formal real estate finance and commodity circulation; third, through these processes, many city-makers become fluent in claiming and realising their right to the city, thus expanding their political agency and citizenship.

The processes of auto-construction in Lima have been thoroughly examined through the work of Turner and Fichter (1972), Lloyd (1980), Matos Mar (1984, 2004), Lobo (1982), Defregori et al. (1986), Cabrera and Villaseca (2007) and Gyger (2019), among many others. Their accounts of everyday city-making consistently show that the social production of housing does not just produce dwellings, but cities and citizenship. Here I argue that it can also act as a de-stigmatisation strategy with deep political implications.

Fundamental to understanding the social production of the barriadas are the invasion of land and their consolidation and progressive development over long periods. In Improvised Cities, Gyger (2019) offers an insightful chronicle of the self-organised auto-construction processes that built Lima's barriadas and, more widely, of the housing policies in Peru from 1954 to 1986. Seen as a means to build grassroots democracy by the Izquierda Unida (United Left), rejected by Shining Path, and re-signified by de Soto's neoliberalism as a seed of entrepreneurship that shifts 'Freedom to Build' to 
'Freedom to Borrow' - among other mutations - auto-construction processes have heralded competing ideological positions and changing relations between authorities and settlers; at times deepening stigmatisation, at others making room for new forms of urban citizenship.

Metropolitan Lima's area increased by over 20,000 hectares between 1981 and 2007 (MML, 2013: 178), through the occupation of desert terrains or eriazo (uncultivated land) in the peripheral ravines that surround the city. As land is increasingly scarce and the scope for further expansion highly limited, the newer the settlements, the higher the risks and challenges faced by newcomers to create inhabitable neighbourhoods.

Over time, different waves of occupation have hit the dry and steep ravines of Lima's peripheral districts, initially through collective land occupations (invasiones in Spanish) and more recently through informal land markets. Both practices are driven by the unmet demand for affordable housing and land in the city (Figure 2). These methods entail a reversed process of urbanisation, whereby some form of precarious tenure security is obtained after claiming settlement in the area, as a means to start the quest for basic services and land titles.

In the 1990s, the first JCM settlements were formed through collective invasiones, followed by further land occupations higher up the hills. At times, this mechanism was even encouraged by the state and supported through what became known as 'planned grassroots urbanisation' (Riofrío, 1991). Planned and unplanned invasions together account for most areas now occupied by the poor across the city. However, unlike earlier collective occupations, the periphery of Lima is currently expanding through a complex web of practices that constantly reconfigure the border of the city. Some of these practices are still driven by collective organisations as a genuine means to reclaim the social function of land; others by what is often locally described as 'informal speculation', a blanket label that itself stigmatises those involved as 'undeserving' (Allen et al., 2017).

Practices under this label range from those of local community organisations gradually occupying the slopes to capture small surpluses in order to ameliorate the area, to the large-scale operations of organised mafias of land traffickers (Lambert, 2021). In the first case, newcomers gain the right to occupy a designated area either by paying a fee or by joining an Agrupación Familiar (AF) or recognised community-based organisation. Although these transactions do not involve land titles, the incorporation of newcomers into an AF's registry provides them with the right to contribute to and benefit from the communal work and investments devoted to ameliorating living conditions and, potentially, to gain some form of land tenure security (Carranza, 2017). Conversely, traffickers invest in a kind of pseudo-ownership, develop layout maps to sell the plots and build access roads and stairs to attract buyers. This sometimes involves profit-sharing alliances between local leaders and traffickers; while other times they operate in conflict with each other.

The land occupied and transacted through these practices originally belonged to the peasant community of Jicamarca, whose collective rights were formally recorded in the Property Registration Office of Lima in 1863 and 1984. While the former Constitution of Peru (1979) recognised communal land transfers, the current constitution (1993) does not. However, a law enacted by President Garcia in 1987 introduced an exceptional mechanism for the disposition of communal lands, enabling the transfer of specific land right uses, such as leasing. Overtime, land traffickers have taken advantage of this legal ambiguity to profit from the Jicamarca community's 


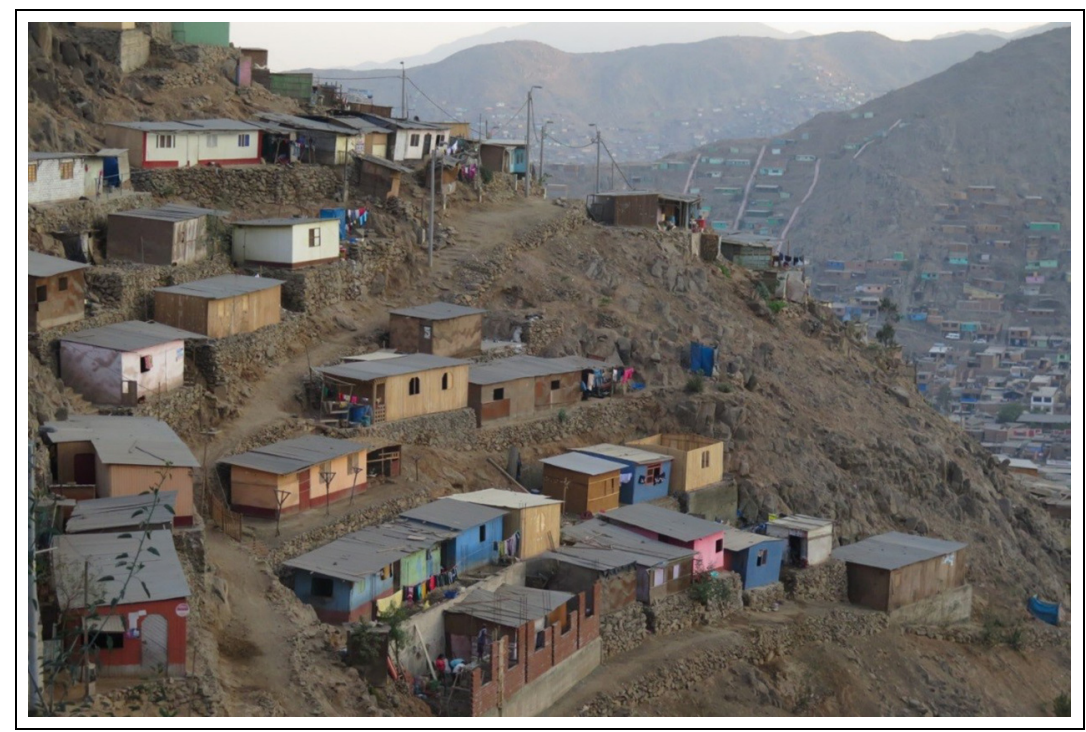

Figure 2. Panoramic view of the different waves of settlements occupying the slopes in JCM. Source: Photo by the author.

autonomy by using and freely disposing of their territory.

Today, land traffickers lead Lima's expansion, imposing their own rules and profiting from the unmet housing and land needs of the poor via illegal mechanisms. These range from buying leases from peasant community leaders to forging signatures that testify to sales or transfers of communal lands allegedly approved in communal assemblies (Escalante Estrada and Miranda, 2020). Peru's media often reports traffickers' violent and intimidating tactics and farreaching networks (Clavel and Dudley, 2017). In 2014, one of Peru's most influential newspapers reported how after Lima's police arrested land traffickers in 22 municipal districts, new gangs rapidly emerged to reconfigure their network (El Comercio, 2014a). As argued by Escalante Estrada and Miranda (2020: 118-19), 'there is a relationship of conflict over land and over who appropriates the sales and revenues between land traffickers, neighbourhood leaders and the residents'. Furthermore, mistrust extends to the peasant community due to a lack of transparency over profit distribution and negotiations with local authorities.

This complex web of land acquisition is driving the expansion of Lima in the interstices between the legal and the illegal, the formal and the informal, through the transversal logics described by Caldeira. While such processes attend to some people's needs, a large number of settlers live in the area without any form of tenure security and with precarious access to water and sanitation. Assistance from the state is absent or inadequate, and frequently tied to political clientelism practices. The latter include popular practices such as 'polladas' - local food celebrations organised to gather funds for communal works - hijacked by political caudillos who donate chickens in exchange for votes; or the use of municipal programmes to build staircases uphill, while supporting 
informal interactions that underlie political exchanges conditioning access to resources. Thus, the relationship between neighbourhood organisations and the state is often one of negotiation of mutual benefits: whether driven by unfulfilled social needs, marginal profit-making or the search for political support.

In comparison to other areas of $\mathrm{SJL}$ District, JCM's settlements have a relatively small, though fast-growing population. Most households comprise young families and single mothers, only a small minority have land titles and only about $20 \%$ enjoy access to electricity and water connections (cLima sin Riesgo, 2015) (Figure 3). Local residents face multiple daily risks and small episodic disasters, such as accidents involving falling, rockfalls, landslides and gastrointestinal and respiratory diseases (cLima sin Riesgo, 2015).

Public and community investments seeking to ameliorate living conditions often lead to increasing land values, propelling new occupations higher on the slopes and reinforcing risk accumulation cycles. The paradox of the city's periphery is synthesised in the low initial investment required to settle, and then the relatively high costs of mitigating the risks faced to inhabit the steep slopes. Consequently, small-scale risks accumulate and intensify, exacerbating the challenges experienced by those settled upslope, pushing them further into risk and stigma traps that cannot be reverted by individual coping practices (Allen et al., 2017). The next section explores the trajectories of two settlers navigating stigma through this process.

\section{Trajectories: Confronting stigma in the periphery of Lima}

\section{Francisco}

I first met Francisco in 2013. He is a male community leader who in 2002 settled with another five families in an uninhabited area of the upper slopes of JCM, now known as Quebradas Verdes (Green Ravines):

I came to this area with my daughter after my wife left. I was always a religious and disciplined man - I used to be in the army and I love God and my country - but, for a while, I went down the wrong path. I started drinking, and little by little I lost everything. Before coming here, I was renting a room in the centre of the city, but that was not life. I became known as a drunk and couldn't keep a job. We lived on top of each other and had to move every six months or sooner if the landlord didn't like your face. I was longing for peace, and a better place to raise my daughter. It was then when a priest who helped me to stop drinking told me about JCM and how many families in the past had claimed this area as their home. I came to visit and immediately knew that this was also a place where I could restart my life, close to God's gifts, our hills and green lomas.

Francisco was redeemed from the stigma of being an 'alcoholic' and able to reinvent himself as 'a reformed man by the grace of God' when he moved to JCM. He deployed his manual skills and connections as a former army member to become a construction worker and built a home and a community. His daughter was then 12 years old and became the 'woman of the house', playing a key role by undertaking domestic chores. Francisco loves his daughter but doesn't acknowledge her role; instead, he sees his 'eloquent command' of Spanish and 'buena presencia' (good appearance) as the attributes that allowed him to become a respected community leader and effective interlocutor with local authorities and service utility providers. Buena presencia is a term commonly used to refer to someone who is light-skinned, and one of the many examples of entrenched racism in everyday speech in Peru and, more widely, In Latin America. 


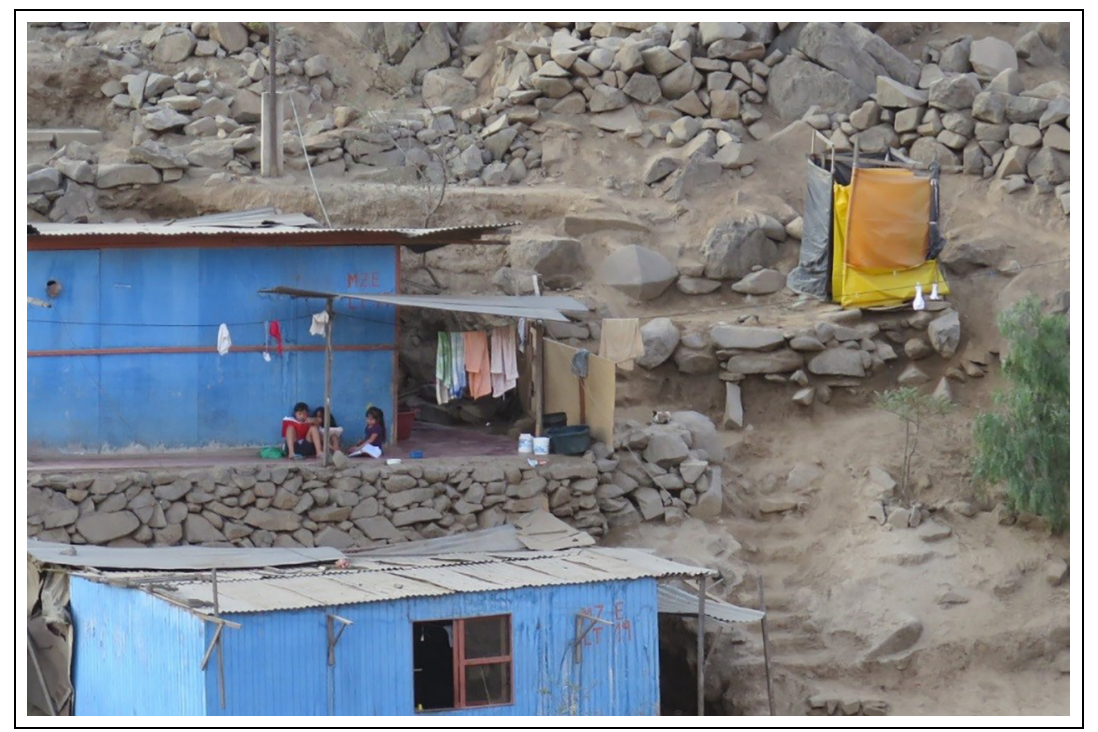

Figure 3. Everyday life in the upslope expansion in JCM.

Source: Photo by the author.

Crucial to overcoming stigma were the possibilities that emerged as Francisco became involved in Lima's peripheral urbanisation processes. During the first years, together with other families, he bought water from settlers further down the slope, who benefited from a tank installed in 1995 by SEDAPAL, the public water and sanitation utility. Lacking sanitation, most households relied then on open defecation in 'silos', shallow holes surrounded by plastic sheets that provide some privacy. Today, $80 \%$ of the 110 families living in Quebradas Verdes continue this practice due to the lack of sanitary facilities.

By 2007, the population in this settlement had doubled and had managed to obtain electricity; and in 2014, less than a third of the households - almost 90 - obtained individual connections to water. Francisco recalls the process: 'We first became organised into an Agrupación Familiar (AF) in 2005 , the only way in which you become to exist in the eyes of the authorities'. Forming an AF involves developing a statute that sets rules for community members and also a certified plan of the settlement: ' $\ldots$ as the leader of the AF, I put my savings and time not only to pay a surveyor to draw a plan, but also to get it certified by the district municipality'.

A certified plan shows how many families live in the area, gives a number or address to each plot and earmarks evacuation areas and areas dedicated to social facilities. It shows who you are as a community, and what you want to become as a neighbourhood. It also establishes the perimeter of the neighbourhood which helps to protect it from encroachment - often by traffickers that unlawfully sell land to newcomers.

A certified plan is the starting point for claiming better access to water and sanitation from SEDAPAL. However, as the costs of building decentralised infrastructure on the slopes tend to be high, SEDAPAL only provides water tanks that serve several neighbourhoods at once. Everything further 
relies on settlers investing in collective and individual connections.

To afford these investments, AF members must raise funds. The only way to do this is by selling further plots on the upper slopes in areas earmarked for collective use and evacuation in their certified plans. Figure 4 shows the modifications made by Quebradas Verdes AF over time, to create further plots on their original plan. As explained by Francisco:

little by little, we carved more and more plots on the plan and then the newcomers to whom we sold these plots carved them on the hills for real. This allowed us to improve our own access to water but not that of the newcomers; their only hope is to repeat the same process which we went through ... [but] once you reach the perimeter of the settlement, your only chance is to sell plots in the sky.

The chances of newcomers raising the necessary funds become slimmer and slimmer, and investment costs grow exponentially as settlements move upslope. Plots are ultimately limited by the steep hills and poor water availability, and the difficulties in expanding human-made infrastructure.

The second year I visited Francisco, the situation had changed drastically. Unlike during previous chats we had had while walking through the settlement, this time he invited me into his home and insisted that we spoke quietly: 'There has been a coup, they [the current AF] called an assembly and kicked me out ... They claimed I was making money from selling plots; they stained my name'. The new AF leaders were more recent settlers, who claimed that after benefiting from the sale of plots, Francisco was now stopping others from doing the same.

According to Francisco, a schism emerged when he tried to stop the last few unoccupied areas of the settlement from being parcelled into further plots. Keeping
Quebradas Verdes 'green' was a key part of Francisco's strategy to destigmatise the area. While other settlers sometimes describe living on the slopes as a stigma in itself, Francisco often used an idealistic rhetoric: attributing value to the 'green' lomas and the proximity of the settlement to God and the sky. He even identified religious symbols in the landscape - such as rocks in the shape of Virgin Mary - arguing that one day Quebradas Verdes would become part of a green corridor linking peripheral settlements and attracting visitors from across Lima.

The discord between Francisco and the new AF leaders arose from the conflicts and power struggles that underpin JCM's peripheral urbanisation processes more widely. In his own words:

Quebradas Verdes [like most settlements in $\mathrm{JCM}]$ is the outcome of the actions of four groups of people: the old settler, the newcomer, the tourist and the corrupt. The 'old settlers' are people like me ... those who came to the area almost two decades ago in search of a place to live. The 'newcomers' are those in need, who keep on coming because they have no alternative options elsewhere in the city. The 'tourists' are people from the lower part of San Juan de Lurigancho and other parts of Lima, who come to see how things go, hoping to grab a piece of land which one day might be turned into a plot either for their children, or to be sold to others. They come and go, and often give up before their dream comes true; this is why we call them tourists [see Figure 5].

Lastly, the 'corrupt' describes the land traffickers who speculate on a large scale, opening roads and carving the hills to generate profits through practices ranging from negotiation with existing settlers, to intimidation and coercion. The strategies adopted by land traffickers can be distinguished from those of community leaders like Francisco and most AFs, as the latter are the expression of collective survival mechanisms to finance 


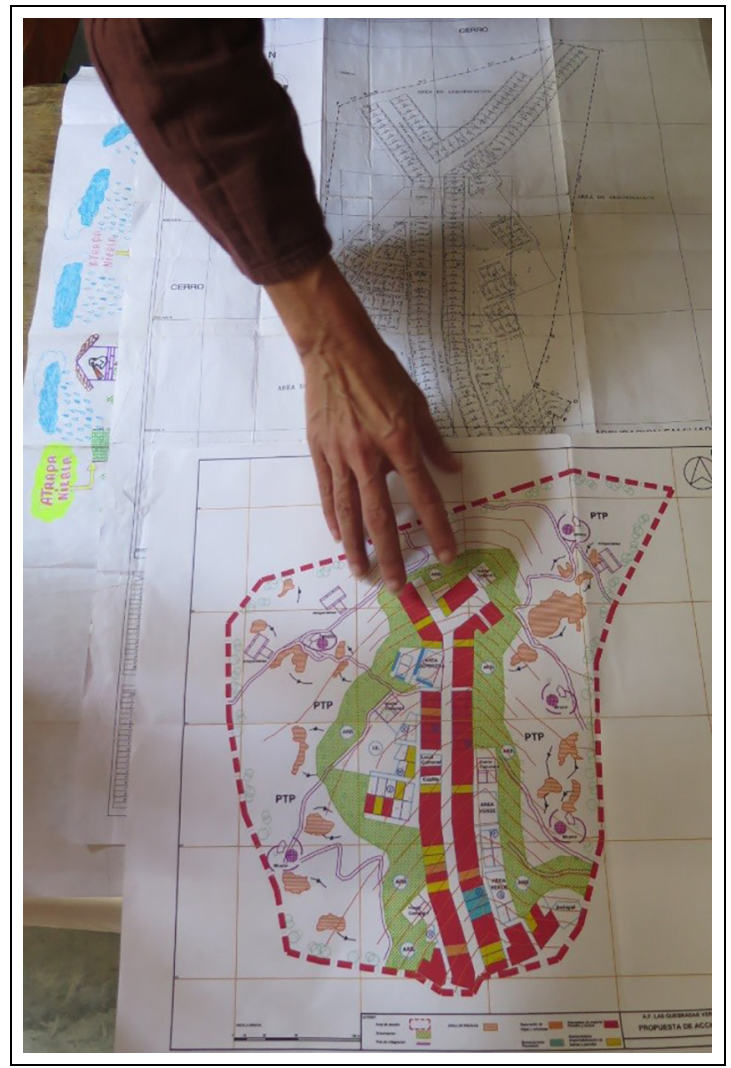

Figure 4. Carving the slopes in JCM: Certified plan and projected extension. Source: Photo by the author.

gradual improvements in the settlements (Allen, 2014).

These four groups - the old settler, the newcomer, the tourist and the corrupt coexist with interrelated practices but different rationales, motives and expectations. While some aim to claim a place within the city, others speculate differently, ranging from individuals attempting to capture small surpluses by carving further plots, to largescale schemes driven by networks of land traffickers.

These practices are, however, often homogenised by the media, reinforcing a perception among the public that renders the slopes' occupation as 'illegal'. For example, El Comercio, one of the most influential newspapers in Peru, has published over the years regular news stressing this narrative, by describing land invasions as criminal acts perpetrated by land trafficking gangs, in association with local residents and local and national officials (see El Comercio, 2014b).

Estela's experience is one of a 'newcomer', labelled as a 'tourist' as she tried to navigate through multiple stigmatising mechanisms running across class, racist and sexist discrimination.

\section{Estela}

Estela arrived in JCM in 2012, a decade later than Francisco. In 2010, she migrated to Lima with her toddler son from her 


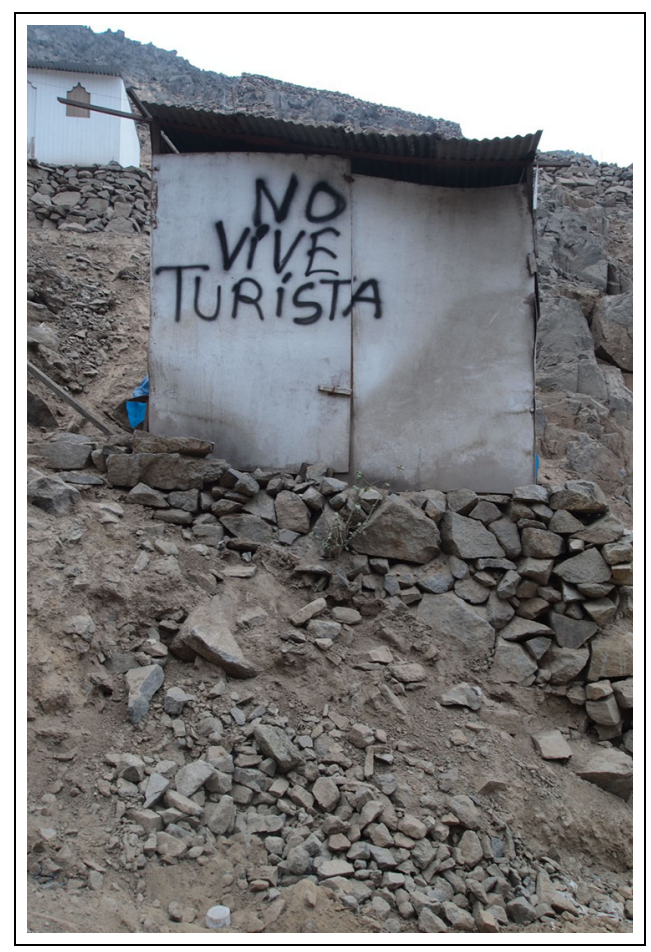

Figure 5. The 'tourist'. The sign states 'Doesn't live here - Tourist', showing the way in which community leaders mark the shacks of those presumed to settle a structure for speculative purposes, rather than with the aim of dwelling. Source: Photo by the author.

hometown in the Province of Ayacucho, leaving all she had in search of a better life:

I come from the sierras [highlands]. Back in my hometown, I had a house connected to the mains, a small shop, people were ready to help and respected me. But life was unbearable, my husband drunk and gambled away anything I could bring home. If I protested, I used to get beaten up. Here in Lima, they call this 'Amor Serrano' [highland love]: Más me pegas, más te quiero [the more you beat me up, the more I love you]. I don't understand why; I never felt that what my husband was doing was right. It makes me angry when people say that, as if we women from the sierras deserve to be beaten up! [...] One day while I was praying for things to change, I realised I could not wait for God to help me; I had to help myself. I packed a few clothes and in the middle of the night sneaked out of the house with my son and took a bus to Lima.

Amor Serrano epitomises a deep belief in Peruvian society and other parts of Latin America, an expression of what Fricker (2007) defines as 'hermeneutical injustice': the incapacity of a society and its institutions to acknowledge the prevalence of domestic violence and to act upon it. It also embodies insidious disrespect, whereby women are presumed to accept their punishment as an expression of love. This practice stigmatises not just women, but also their ethnicity, implying that women from the Andean highlands engage in backward relations that conflate fear and love. Myers' (1973) ethnographic exploration of the historical stigmatisation of serranas in the pueblos jóvenes of Lima exposes the agonising conflict between dominant and dominated cultures and languages that intersect gender and ethnicity, and the challenges serranas face to navigate stigmatising practices reproduced through mocking, violence and discrimination.

As a single mum and serrana migrant who only spoke Quechua upon her arrival in Lima, Estela entered a path of structural stigmatisation, first as a tenant in the city's historic centre, and later after settling in Lima's periphery. For the first two years, she rented a room in central Lima and worked long hours as a 'maid'. In Peru, domestic workers have been historically casted socially and legislatively as second-class citizens through Law 29,786 (Ministerio de Trabajo y Promoción del Empleo, 2003), which sets their contractual rights as defined by the conditions 'agreed by the parties'. While a new law advancing their rights was passed in 2020, for decades, female migrant domestic workers in Lima have been stigmatised due 
to the intersectionality of their ethnicity/race, social class, migrant status and gender (Pérez and Llanos, 2017). Poorly paid and at the mercy of their employers regarding wages, working hours and conditions, women like Estela consistently face discriminatory practices and limited socioeconomic mobility, as they juggle productive and reproductive roles and responsibilities (Bunster and Chaney, 1985).

Estela recalls her experience:

When I arrived at Lima, I found that things were much harder than I expected. I was used to running my own shop, I was good with numbers and chatting with clients, but I spoke little Spanish and was told that I lacked buena presencia. With no savings to even venture into street vending, I had no option but to work as a maid.

Although often denied, racism and class biases continue to shape social relations in Peru, with those from the highlands often depicted as culturally backward and socially and economically deprived (Alcalde, 2010; Valdivia et al., 2007). This, added to being a single mum - therefore unable to work longer hours 'con cama adentro' (as a live-in maid) - put Estela in a highly disadvantaged position when negotiating her working conditions. Hiring 'cama afuera' (live-out maids) is frequently seen as a less-favoured option, and is portrayed as a charitable action:

On reflection, I think I have become a stronger woman since coming to Lima; I am in control of my body, my income, the future of my child ... Yet, I often feel disrespected. Last year, when I asked for a small salary increase in the house where I work, I was told that if I didn't like my job, I should go back to where I came from. My boss said that those of us coming from the 'sierras' are all the same: once we have something to eat, we bite the hand that feeds us.
Narratives of the 'ungrateful other' are commonly endorsed by middle- and upper-class 'white' Limeños. However, such statements are not seen as racial-ethnic discrimination, but rather as factual, by those who selfdefine themselves as 'gente educada $y$ decente' (educated and decent people). Estela had to calculate carefully to keep a 'cama afuera' job, putting up quietly with such remarks while finding ways to keep her son safe during the long hours at work.

'After arriving in Lima, I rented a tiny room in a quinta in the historic centre': quintas are listed residential buildings from the colonial era, which over time have been subdivided to accommodate tenants in each room. Living conditions are often precarious and overcrowded:

... I had to lock my son in the room while going to work, for his own security, poor thing ... he would spend hours alone until I managed to buy a TV, and then that was his only company! You must see how tough life is behind the facade of those old buildings; you think there will be running water and toilets that work, but that's not the case. Every morning, I had to collect water from a common tap in the courtyard, fill as many buckets as I could store in our room and then go to work until the late evening. As for toilets, well, there was only one to be shared with another 10 families, so hard to keep it clean and the queues so long that I ended up keeping buckets in our room that I emptied late at night ... I was ashamed others would see that I was living like an animal, but I guess everybody had to do the same.

After two years of renting in different quintas under similar conditions, she decided she had had enough:

One morning, things got worse, a gang got into the property and broke the pipes ... when we woke up, the whole building was flooded, and we lost much of what we had. I went to work 
but could not stop crying, and then Liliana, the cook in the house where I was working, asked me to move in with her in the hills of Lurigancho, until I could save a bit of money to flatten a plot there and build a shack.

Estela's experience recalls the common practice of quiet forced evictions, where hired gangs intimidate tenants and vacate the quintas to redevelop the land. Broken pipes flood common areas and weaken the adobe structures, often provoking the partial collapse of buildings beyond repair. This pre-empts their demolition and opens the way for new, higher density and more profitable buildings. Safety considerations are used deliberately to remove tenants and buildings listed as historic heritage.

Estela and her son moved in with Liliana, who had settled in JCM back in 2004 in a settlement known as '12 Octubre'. Over time, Liliana and her husband had managed to occupy a plot on the lower part of the slope, first building a shack, then little by little replacing it with a modest brick house. After five years of depending on settlers downhill for water via hoses and buckets, Liliana, together with another 25 households, secured a water connection from the public utility. Although water is only available twice a week, they managed to escape water poverty by joining forces with the inhabitants of another three settlements, who together demanded a new water tank from SEDAPAL. Liliana recalls this process:

Without joining forces with others from neighbouring settlements, any request to SEDAPAL has no weight. They told us that they would not consider investing in a new tank for people without titles, unless the tank was to benefit at least 200 families. It was at that point that we got together and started to attract newcomers. Selling plots gave us enough funds to pay for our own connections once SEDAPAL built the tank ... because if you are lucky, they go as far as bringing water close to the area, but not to your plot.
Estela thought that she could follow Liliana's steps. In the hills of JCM nobody would look down on her for being a serrana. If she could work hard and wait, one day another tank might be built bringing water closer to her plot. She might even gain access to her own latrine, and later perhaps a land title. This is what some refer to as the 'urbanisation of hope', a process of reverse urbanisation that starts with the invasion of unserved land, in the hope that public, collective and individual efforts and investments will improve its liveability.

But Estela's trajectory was not like Liliana's. Without a partner to share productive and reproductive tasks, she fell back repeatedly into poverty and stigma traps. The statute of most AFs seeks to protect the social function of land by giving priority to those most in need. As a single mum, Estela fulfilled this condition. However, most statutes also stipulate that those granted a plot - whether through purchase or by paying fees to join an AF - should inhabit it within six months of joining the community. Estela tried to meet this condition but, as she explains:

it is impossible to meet this deadline when your capacity to turn earth into a home is limited. I could only work on the plot once a week at best, flattening the terrain with a little spade. But even when I managed to do so and to build a shack, I could not inhabit it because of the lack of water ... thus my deadline expired, and again and again I had to move further up the slope to start it all over again ... The third time this happened to me, I was determined to change my bad luck. I worked endlessly, but before I could move in with my son, I came one Sunday and found my shack burnt down. I was not a 'tourist' but was treated like one. Don Virgilio, the land trafficker who was opening a new settlement at the top of the slope, sent his guys to put fire to my shack and I lost everything again.

Forced to move further upslope, Estela found herself a plot in an area disputed by 
the leaders of 12 de Octubre and Don Virgilio - the latter being the name given to figureheads operating on behalf of traffickers. She learnt that in fact, her new AF leaders had agreed with Don Virgilio to give up their claims over land near the edge of the settlement in exchange for a small share of the land trafficker's profits. This was why her shack was burnt down, and she had then to negotiate with Don Virgilio and raise enough money to buy from him the plot she had flattened to avoid being displaced once again (Figure 6).

Estela knew that, as a newcomer, she was vulnerable, and she was suspicious and fearful of everyone. Alone with her son, she could do little to protect her few belongings. Calling the police was not practical. Neither was asking for help from the AF, as its leader had come to an arrangement with Don Virgilio to 'set peace in the area'. When asked about other support available at the time, she recalls finding herself in limbo: 'the government, the Church and NGOs in the area help with things like children's vaccinations, milk supplements or training ... but these are of little help when what you need is a roof, water and roads'. Throughout her life in Lima, Estela was subjected to different stigmatising practices and forced to rely on charitable and discontinuous support as a 'woman in need', not as an entitled citizen.

Of significance to both trajectories is the way in which the conflict between Shining Path and the Government of Peru, which even if dormant since the late 1990s - continues to permeate life in the barriadas of Lima, played out in interactions across AFs and with the state, while acting as a site of stigmatisation. Many earlier settlers in SJL coming from the highlands of Ayacucho epicentre of Shining Path foundation, recruitment and violent conflict - recall facing discrimination and violent intimidation as potential 'terrorists' (Muñoz et al., 2006). This adds another layer of stigmatisation for

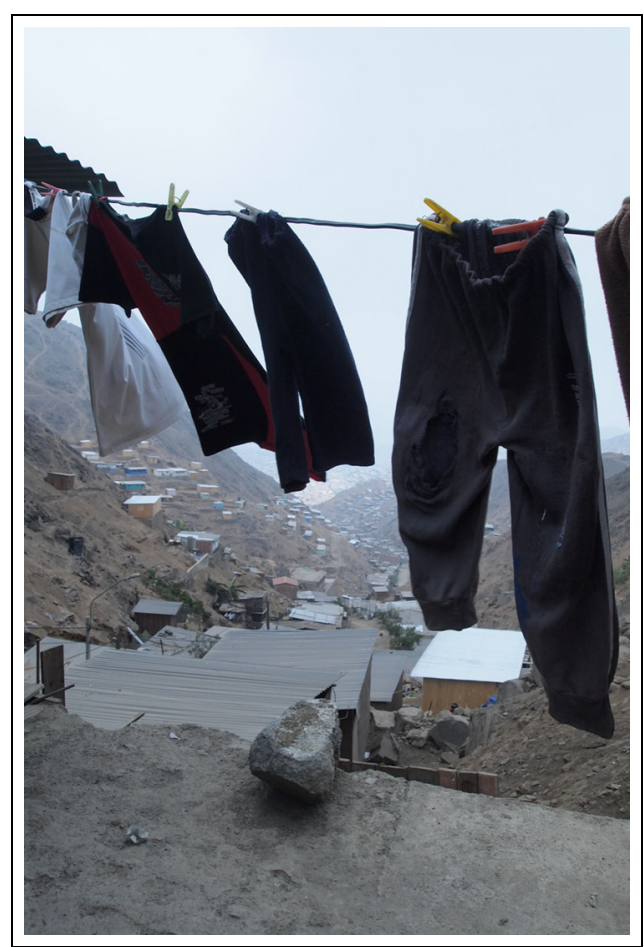

Figure 6. View from Estela's 'plot' on the hills before her shack was burnt down.

Source: Photo by the author.

female serranas, like Estela, and partly explains why Francisco could capitalise on his past in the army to forge sympathetic alliances with former army members among SJL District's officials.

\section{Navigating through trajectories of stigma and infrastructural uncertainty}

Being able, or not, to draw on collective organisation and action is key to the extent to which poor women and men might overcome stigmatisation and escape insecure tenure and infrastructural uncertainty. This does not mean that stigma is only a process produced and counteracted by stigma receivers and reproducers, and their relative 
access to and use of social resources. Stigmatisation operates within a wider network of social, political and material relations, ranging from state-led laws and policies through infrastructural entitlements that reinforce discrimination, to widely endorsed stereotypes and prejudices, at points even reproduced by local community organisations engaged in peripheral urbanisation processes.

The different outcomes of Francisco and Estela's trajectories are largely explained by the different possibilities they faced in exerting their agency as part of a collective. For Francisco, everyday planning became the main mechanism by which he sought to overcome stigma. Leading the elevation of Quebradas Verdes from a piece of eriazo land to the place where 'God marked his presence and blessing to the dispossessed' was, in his own words, central to regaining the status he lost while he was a tenant in the historic city centre. His dream was facilitated by being a man in a context where local leadership is still highly masculinised, relying on his daughter to undertake domestic chores and his connections through his affiliations with the army and the Church. Estela's aspirations were humbler. She dreamed of building a home in a place where her ethnicity, gender and socio-economic status as a maid and single mother wouldn't make her the 'other'. Yet, stigmatisation took new forms as she travelled from the historic centre to the periphery of Lima. She was first a 'newcomer' and later a 'tourist' trapped into a new web of stigma-making strategies and isolated from the rest of the community in her place-making efforts.

One could argue that Francisco's greater mobility away from stigma and infrastructural uncertainty came because he was an older settler, and therefore Estela might become able to follow a similar path over time. However, in reality her prospects of overcoming the status loss imposed by multiple layers of stigma are slim. Estela's personal efforts to condition a plot on the hills and restart the process again and again were incommensurable, but the weight of being treated by others as the recipient of charity or being mistrusted as a 'tourist' blocked her away from the opportunities afforded by collective local action. Francisco's trajectory is more merciful than Estela's. For several years he managed to overcome the status loss experienced before moving to JCM. Yet, as grassroots processes in Lima's peripheral urbanisation became entangled with those of land traffickers, he lost the respect of his peers and the dream of a better future for him and his community.

Thus, what a person succeeds in doing or being - from procuring access to water to preserving self-respect - is only a small part of the de-stigmatising process. The agency of Francisco and Estela to overcome stigma was not just contingent on their individual capacities but relied on their differential engagement with collective action processes. This highlights that overcoming stigma through everyday city-making relies on the possibilities of entering such domains as a collective process, but also points to the contemporary dilemmas of collective action that in turn might reinforce stigma. Without romanticising the past, a fundamental difference between earlier auto-construction processes and those that build the peripheral barriadas of Lima today is that the latter mimic the former's practices and rituals, but have a more ambivalent political identity, function and purpose. Everyday city-making collectives - such as the AFs have become boundary-makers, creating new borders and frontiers between old dwellers and newcomers, between insiders and outsiders, while entangled in a market-led logic, practices of political clientelism and constant negotiation with land traffickers.

In different ways, both Estela and Francisco were at the heart of negotiated spatial strategies to control the shifting 
boundaries of peripheral urbanisation in Lima. Yet, the material conditions and spaces they inhabited demarked contrasting possibilities, with shifting boundaries marking the difference between de-stigmatisation and stigma traps. What their trajectories highlight is the interplay of social, temporal and spatial relations. The materiality and spatiality of stigmatisation processes are not just outcomes, but drivers of housing insecurity and infrastructural exclusion.

Across the five components identified by Link and Phelan (2001) in their conceptualisation of stigmatisation as a process, 'separation' plays a pivotal role in locking or unlocking people into stigma traps, well before discrimination can be socially or individually recognised. Therefore, understanding the political space for de-stigmatisation strategies requires considering the mutating formation of collective identities: how 'us' and 'them' are mutually defined over time. This implies looking into how individuals and groups engage in challenging or reinforcing boundaries when responding to stigmatisation, both socially and spatially. It also demands a deeper understanding of the repertoire of collective mechanisms available in particular times and contexts.

Francisco and Estela's trajectories show that stigmatisation is reinforced through multiple mechanisms and plays an insidious role in perpetuating and justifying endless forms of discrimination at work, at home, in the community and in political spheres. This defines how, where and why some citizens receive more protection and support than others from the state and from intermediary and community organisations. Stigma serves to silence injustices and to confine stigma to the stigmatised, who in turn must endlessly plan to cope with insecurity, uncertainty and a lack of social protection.

Everyday city-making practices can be seen as de-stigmatisation strategies adopted by ordinary people, simultaneously deployed to improve their living conditions and to address the structural drivers that make them vulnerable. Exploring de-stigmatisation strategies therefore requires examining the socio-cultural and political frames that ordinary citizens in informal settlements mobilise to make sense of their experiences and to determine how to negotiate material and symbolic boundaries. It also involves observing how such responses are enabled and constrained by institutions, intermediary groups, cultural repertoires and contexts. De-stigmatisation strategies imply ongoing calculation of the 'space for change' available under different circumstances, where such space is carved within individual and collective capacities to challenge multiple layers of disabling stigmatisation. The 'where' and 'when' of the struggles faced by those stigmatised matter as much as who they are, not just as the outcome of their intersectional identities but, above all, as the result of the intricate web of social, spatial and political relations that define who can escape stigma traps and who cannot.

\section{Acknowledgements}

I would like to express my deep gratitude to the real 'Estela' and 'Francisco' and to many other city-makers of Lima for sharing their experiences, trajectories and insights over so many years. My gratitude to colleagues and friends at CENCA, CIDAP and Foro Ciudades para La Vida for their guidance and support throughout my own journey across the city, especially to Carlos Escalante Estrada, Silvia de los Rios and Liliana Miranda. Big thanks also to Rita Lambert and other UCL DPU colleagues at ReMapLima: Mapping Beyond the Palimpsest and cLIMA sin Riesgo (www.cLIMAsinRiesgo.net) for hours and hours spent in the field and insightful exchanges, and to the funders of both projects: UCL The Bartlett and the Climate Development Knowledge Network (CDKN) respectively.

I would also like to thank Haim Yacobi and Hanna Baumann - editors of this Special Issue - 
and the anonymous referees who reviewed the article, for their helpful advice and insightful feedback on previous drafts.

\section{Declaration of conflicting interests}

The author declared no potential conflicts of interest with respect to the research, authorship, and/or publication of this article.

\section{Funding}

The research that underpins this article was conducted with the financial support of The Bartlett Faculty of the Built Environment Research Materialisation Grant 2013 at University College London (UCL), and the Climate Development Knowledge Network (CDKN).

\section{ORCID iD}

Adriana Allen (iD https://orcid.org/0000-00016215-5962

\section{References}

Alcalde MC (2010) The Woman in the Violence: Gender, Poverty and Resistance in Peru. Nashville, TN: Vanderbilt University Press.

Allen A (2014) The old settler, the newcomer, the tourist, and the corrupt. DPU Blog. Available at: https://blogs.ucl.ac.uk/dpublog/2014/05/07/ the-old-settler-the-newcomer-the-tourist-andthe-corrupt/ (accessed 7 May 2016).

Allen A and Hofmann P (2017) Relational trajectories of urban water poverty in Lima and Dar es Salaam. In: Lacey A (ed.) Women, Urbanization \& Sustainability. Practices of Survival, Adaptation \& Resistance. London: Palgrave, pp. 93-117.

Allen A, Zilbert Soto L, Wesely J, et al. (2017) From state agencies to ordinary citizens: Reframing risk-mitigation investments and their impact to disrupt urban risk traps in Lima, Peru. Environment and Urbanization 29(2): 477-502.

Bunster X and Chaney E (1985) Sellers \& Servants: Working Women in Lima, Peru. New York, NY: Praeger.

Cabrera T and Villaseca M (2007) Presentes, Pero Invisibles: Mujeres Y Espacio Público En Lima Sur. Lima: Desco, Programa Urbano.
Caldeira TP (2017) Peripheral urbanization: Autoconstruction, transversal logics, and politics in cities of the global south. Environment and Planning D Society and Space 35(1): 3-20.

Carranza X (2017) Settling for disaster: The construction and governance of urban environmental risk in Lima's informal settlements. BSc thesis, Brown University, USA.

Chase J, Crawford M and Kaliski J (1999) Everyday Urbanism. New York, NY: Monacal Press.

Clavel T and Dudley S (2017) How urbanization and land trafficking go hand-in-hand in Peru. InSight Crime News, 4 July. Available at: https://insightcrime.org/news/analysis/how-urba nization-and-land-trafficking-go-hand-in-handin-peru/ (accessed 20 January 2020).

cLima sin Riesgo (2015) JCM Community Survey. Research project supported by CDKN. Available at: https://climasinriesgo.net/ (accessed 20 January 2020).

Dear M and Laws G (1986) Anatomy of a decision: Recent land use zoning appeals and their effect on group home locations in Ontario. Canadian Journal of Community Mental Health 5(1): 5-17.

Defregori C, Blondet C and Lynch N (1986) Conquistadores De Un Nuevo Mundo: De Invasores a Ciudadanos En San Martin De Porres. Lima: Instituto de Estudios Peruanos.

El Comercio (2014a) High complex crimes squad from the national police of Peru, Division de delitos de alta complejidad. Available at: https://elcomercio.pe/peru/diviac-cumple-dosanos-lucha-frontal-crimen-organizado-noticia550938 (accessed 10 June 2020).

El Comercio (2014b) Invasiones amenazan la expansión urbana al norte y sur de Lima. Available at: http://elcomercio.pe/lima/ciudad/invasiones-amenazanexpansion-urbanaal-norte-y-sur-lima-noticia-1775539 (accessed 10 June 2020).

Escalante Estrada C and Miranda L (2020) The hillside poor at risk? Land trafficking in Jose Carlos Mariátegui at the outskirts of Lima, Peru. In: Van Den Broeck P, Sadiq A, Hiergens I, et al. (eds) Communities, Land and Social Innovation: Land Taking and Land Making in an Urbanising World. Cheltenham: Elgar Publishing, pp. 110-124. 
Fine M and Asch A (1988) Disability beyond stigma: Social interaction, discrimination, and activism. Journal of Social Issues 44(1): 3-21.

Fricker M (2007) Epistemic Injustice: Power and the Ethics of Knowing. Oxford: Oxford University Press.

Goffman E (1961) Stigma: Notes on the Management of Spoiled Identity. Englewood Cliffs, NJ: Prentice Hall.

Gyger H (2019) Improvised Cities: Architecture, Urbanization and Innovation in Peru. Pittsburgh, PA: University of Pittsburgh Press.

Hicks S and Lewis C (2020) Nobody becomes stigmatised 'all at once': An interactionist account of stigma on a modernist council estate. Sociological Review 68(6): 1370-1385.

Holston J (2009) Insurgent citizenship in an era of global urban peripheries. City \& Society 21(2): 245-267.

James SA, Strogatz DS, Wing SB, et al. (1987) Socio-economic status, John Henryism, and hypertension in blacks and whites. American Journal of Epidemiology 126(4): 664-673.

Lambert R (2021) Land trafficking and the fertile spaces of legality. International Journal of Urban and Regional Research 45(1): 21-38.

Link BG and Phelan JC (2001) Conceptualizing stigma. Annual Review of Sociology 27(1): 363-385.

Lloyd P (1980) The Young 'Towns' of Lima. Cambridge: Cambridge University Press.

Lobo S (1982) A House of My Own: Social Organization in the Squatter Settlements of Lima, Peru. Tucson, AZ: University of Arizona Press.

Matos Mar J (1984) Desborde Popular y Crisis del Estado. Lima: Instituto de Estudios Peruanos.

Matos Mar J (2004) Desborde Popular y Crisis Del Estado: Veinte Años Después. Lima: Fondo Editorial del Progreso.

Metropolitan Municipality of Lima (MML) (2013) Plan Regional de Desarrollo Concertado 2012-2021. Lima: MML.
Ministerio de Trabajo y Promoción del Empleo (2003) Ley de los Trabajadores del Hogar. Available at: http://www.mintra.gob.pe/contenidos/archivos/prodlab/LEY\%20DE\%20LOS $\%$ 20TRABAJADORES\%20DEL \%20HOGAR \%20Ley\%20No.\%2027986\%2003-06-03.pdf (accessed 7 May 2019).

Muñoz I, Paredes M and Thorp R (2006) Collective Action, Conflict and Ethnicity in Peru. Oxford, CRISE Working Paper No. 24.

Myers S (1973) Language Shift Among Migrants to Lima, Peru. Research Paper no. 147. Chicago, IL: Department of Geography, University of Chicago.

Pérez LM and Llanos PM (2017) Vulnerable women in a thriving country: An analysis of twenty-first-century domestic workers in Peru and recommendations for future research. Latin American Research Review 52(4): 552-570.

Reissman CK (2000) Stigma and everyday resistance practices. Gender \& Society 14(1): 111-135.

Riofrío G (1991) Producir La Ciudad (Popular) De Los '90: Entre El Mercado Y el Estado. Lima: Centro de Estudios y Promoción del Desarrollo.

Solanke I (2019) Discrimination as Stigma: A Theory of Anti-Discrimination Law. Portland, OR: Hart Publishing.

Turner J and Fichter R (1972) Freedom to Build. New York, NY: Macmillan.

Tyler I and Slater T (2018) Rethinking the sociology of stigma. Sociological Review 66(4): 721-743.

Valdivia N, Benavides M and Torero M (2007) Exclusión, identidad étnica y políticas de inclusión social en el Perú: El caso de la población indígena y la población afrodescendiente. In: Grade (ed.) Investigación, Politicas $Y$ Desarrollo En El Perú. Lima: Grade, pp. 603-655. 